\title{
DISCUSSION ON A MINORITY LANGUAGE DEVELOPMENT: DIFFERENT JUDGMENTS ON THE USE OF THE BACK-BURDEN IN BASQUE
}

\begin{abstract}
Овај чланак се бави питањем реда елемената у баскијском језику у окружењу у којем се проза развија како би испунила нове комуникативне захтеве наметнуте овом мањинском језику. Након представљања неких важних карактеристика такозваног референтног оквира постављања значењског фокуса на крај реченице (енгл. реар-бурден) у баскијском језику, представљен је истраживачки рад у којем су анализиране две групе испитаника различитог нивоа образовања, са циљем да се упореди њихово понашање у вези са реченицама у којима је граматички елемент са највећим семантичким фактором смештен на крај реченице. Исходи показују да је група младих универзитетских студената приказала приметно већу склоност ка реченицама горе описаног типа, у односу на појаву примећену у групи од 8 стручњака са већим животним и академским искуством, са којима су упоређени. Предложена су два комплементарна разлога као објашњење резултата: 1) зрелији стручњаци су свеснији комуникацијских проблема који настају коришћењем овог типа реченица; 2) млади људи су се едуковали у окружењу у којем је на снази био такозвани „идеалистичко-идиосинкратички приступ“ стандардизацији баскијског језика.
\end{abstract}

Кључне речи: баскијски језик, вишејезично друштво, мањински језик, развој писане прозе, речи ред у реченици.

\section{The framework of reference}

With some short and practically marginal exceptions, Basque language has been more or less ignored (if not banned or persecuted) as a means of communication for formal settings by every established political power for its whole known history, until the last quarter of the $20^{\text {th }}$ century (Euskaltzaindia, 1977). At that time, the political organization of the part of the Basque Country in Spain turned from General Franco's dictatorship into a formal democracy based on election of politicians as representatives of the population's will. As a result, political power was shared to some extent between the Spanish Central Government and the 17 Autonomous 
Communities emergent at the end of the dictatorship. Some of these recently created or recognized communities had their own specific languages differing from the generally spoken Spanish. Autonomic governments had a chance to apply new language policies within their territory, and as a result some minority languages were acknowledged as co-official along with Spanish which continued to be official all over the territory of the whole Spanish state: this is the case for Galician, Catalonian and Basque languages. In other autonomous communities, regional languages other than Spanish were not given that high status, as in the case of Asturian and the Aragonese. Within this context, and supported by the new language policies applied by the Basque Autonomous Community and the Navarrese Foral Community, Basque started to be more widely used in formal settings over the last quarter of the $20^{\text {th }}$ century, in the framework of a strong socio-politico-cultural movement aiming at achieving the normalization and revitalization of the co-official minority language. As a result of that movement Basque language entered formal domains like the educational arena, mass-media and Civil Services.

However, the introduction and spread of Basque language in these novel areas did not occur without problems and some difficulties had to be overcome. On the one hand, in general terms it can be said that Basque language had scarcely been used in formal settings, and consequently it hadn't had enough training in those new formal arenas at least at the same level as the very strong languages in its surroundings had had (Spanish for the part of the Basque Country in Spain and French within the French state). On the other hand, at the time of the first introduction of Basque language in formal settings most of the population (particularly the urban part, related to industry) did not speak Basque. Besides, as a consequence of the previous language policy applied by General Franco's dictatorship against Basque language, the relatively small number of Basque speakers had been deprived of formal/academic study of their own heritage language, so that their knowledge about tradition was very locally limited and their confidence of their own "language-goodness" probably would be really low.

So, by the time of the beginning of the normalization issue in the Basque Country in the late $20^{\text {th }}$ century, there was a need to find and experiment with model patterns to develop Basque to be used in the growing 
number of written expository and argumentative texts typically performed in the above-mentioned formal domains of use of the language. In other words, it can be said that Basque language had a need to meet new demands, while at the time there was pretty little tradition available for that, and the existing one was almost completely unknown even for most of the Basque users themselves because of the lack of use and study of the language in settings like the educational arena.

When it came to finding references for developing Basque formal written prose, the model pattern most easily available was mainly an approach presented and promoted at the beginning of the $20^{\text {th }}$ century, before the Spanish Civil War, in the work "Erderismos" by Seber Altube, in 1929 (Altube, 1975), following the ideological influence of Azkue, shown by Hidalgo (1995). In spite of some well-argued criticism against relevant features of this pattern (Mitxelena, 1968; Villasante, 1979, 1988), it became predominant at the early times of the normalization process over the seventies and eighties of the past century. This proposal has been called the "idealistic-idiosyncratic approach" (Maia, 2014) and it was the one mainly followed by professionals in the above mentioned formal domains. This model pattern for the Basque prose development claimed a specific and particular way to organize the elements of the sentence in Basque, opposite (and even idealistically antagonistic) to the order of the elements in the surrounding/neighbouring Spanish language. According to this approach, one of the most significant features strongly recommended for developing a "genuine" Basque prose was the basic preference for putting the verb in the last part of the sentence. However, this preference for a supposedly highly different way to organize the order of the elements of the sentence in Basque in order to make its uniqueness evident would bring about some difficulties into the task of developing an efficient Basque prose.

In fact, through experiencing this "idealistic-idiosyncratic" approach for some years a number of problems were detected regarding the communicative efficiency of the prose built following the criteria attached to the pattern. One of the most relevant difficulties is the so-called "back-burden" or "rear burden" of the Basque language, first clearly identified as a problem by Zubimendi \& Esnal (1993). The "back burden" or "rear burden" has been defined this way (Maia-Larretxea, 2015): it is the effect that occurs when 
some key elements for gradual processing of the message (e.g. the verb) are pushed back towards the end of the sentence (the rear part of it), thus delaying and making more difficult the comprehension of the whole message.

So, after having been seen as a particular unique feature of the Basque language to be promoted for distinguishing Basque prose from other surrounding languages' regarding the phrase-order or element-order of the sentences, the "rear burden" feature started to be deemed a source of problems for an efficient written prose to develop. After having detected some disadvantages caused by this problem, various scholars and specialists have been putting forward a number of proposals in order to reduce the negative consequences of the rear-burden (Hidalgo, 1995, 2002; Alberdi \& Sarasola, 2001; IVAP, 2005; Berria, 2006; Kaltzakorta, 2007, 2012; Aristegieta, 2009; Amuriza, 2010; Euskaltzaindia, 2011; Agirre, 2013; Garzia, 2014).

Thus, in general terms it may be said that at present there are different conceptions and practices about how to organize the phrase-order in the Basque written formal sentence: in fact, whilst some instances show that they are still following a relatively back-burdened phrase-organization, other examples make apparent that their users try to promote alternative patterns so that the rear-burden can be reduced (Maia, 2014). Within this context, we support the idea that an evolution may be taking place on this issue over the last few decades: from the prevalence of the pattern called idealistic-idiosyncratic and its attached rear-burden problems at the beginning of the normalization process of Basque, nowadays an increasing tendency to build sentences with a lower rear-burden can be observed. This is the setting in which the following research work has been conducted in order to provide information about the criteria and trends held by some users of the language with different levels of proficiency in the use of the Basque logical-discursive prose.

\section{An example to explain the rear-burden}

In order to make clearer what we mean by the term rear-burden we will now turn to an example in which that concept can be better understood by using a real Basque sentence and its rough translation into English.

Firstly, we point out a pair of sentences in Basque (1a and 1b). Both sentences are grammatically correct although their phrases and elements are put in two different orders: 
(1a) [Honegatik], [eskatuko diet] ${ }_{2}$ [irakurle guztiei] ${ }_{3}$ [ez ditzatela haiek higuindu] ${ }_{4}$ [liburu honetako irakasmen berriak] ${ }_{5}$ [egi-gabeak dirala] ${ }_{6}\left[\right.$ [jakin arte] ${ }_{7}$.

(1b) [Honegatik] _ [liburu honetako irakasmen berriak] ${ }_{5}$ [egi-gabeak direla] ${ }_{6}$ [jakin arte] $]_{7}\left[\right.$ ez ditzatela haiek higuindu] ${ }_{4}\left[\right.$ irakurle guztiei] ${ }_{3}$ [eskatuko diet] ${ }_{2}$.

The main verb is highlighted in bold letters; it occupies the $2^{\text {nd }}$ place in the order of the elements in $\mathbf{1 a}$, and the $7^{\text {th }}$ position in $\mathbf{1 b}$. In terms of syllables, the main verb begins at the $5^{\text {th }}$ one in $1 \mathbf{a}$ while it starts at syllable 48 in the organization represented by $\mathbf{1 b}$. The difference is really huge: $48-5=43$.

Next, we translate roughly into English those two sentences (in a kind of loan translation), thus obtaining the following respective sentences (2a and 2b):

(2a) [That's why] $]_{1}$ I'll beg ${ }_{2}$ [all the readers] ${ }_{3}$ [not to look down on them $]_{4}$ [until knowing] ${ }_{5}$ (that) [the new lessons of this book] [are lacking in truth]

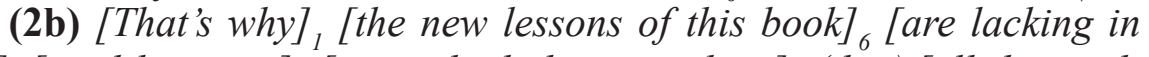
truth] ${ }_{7}$ [until knowing] ${ }_{5}$ [not to look down on them] ${ }_{4}$ (that) [all the readers $]_{3}\left[\right.$ I'll beg] ${ }_{2}$.

The great contrast between the two element-orders can easily be appreciated (being 2 the position of the main verb):

- The order in 2a: 1-2-3-4-5-6-7 has been changed into the order in 2b: $1-6-7-5-4-3-2$

In these two examples in (rough) English the beginning of the main verb of the sentence, which is crucial for a gradual processing and correct understanding of the whole message, moves from $3^{\text {rd }}$ syllable (in the sentence identified as $\mathbf{2 a}$ ) to $31^{\text {st }}$ syllable in the sentence called $\mathbf{2} \mathbf{b}$.

Thus, we claim that the sentences numbered (1b) and (2b) have a heavier rear-burden than their corresponding sentences identified as (1a) and (2a), and therefore, because of the higher rear-burden, the efficient comprehension of that message (understanding at first reading) becomes more difficult than in the case of a sequence with a lighter rear-burden.

\section{The research work}

Introduction. After having analysed the literature concerned and having sought opinions and proposals by different authors tending to re- 
duce the rear-burden of a variety of sentences in Basque, we hypothesized (Maia, 2014) that an evolution is taking place on the issue of the order of the components of the sentences in Basque written logical-discursive prose (in this kind of prose the utterances tend to be longer and more complex than in informal speech). At the beginning of the normalization and revitalization process of the Basque language in the last quarter of the $20^{\text {th }}$ century the predominant model pattern aimed at constructing a very peculiar written prose in Basque, paid little attention (if any) to its communicative efficiency. An important goal for this approach to achieve was showing how different the organization of the sentence was in Basque when opposed to Spanish (the surrounding majority strong language), thus highlighting by contrast the uniqueness of Basque prose.

However, Basque language entered quite massively the educational arena about the beginning of the eighties of the past century, and, as the language started to be really used in communicative formal contexts, professional users of the language noticed that the predominantly theoretical pattern was not able to meet as efficiently as needed some of the relatively novel communicative demands imposed on the language. As a consequence, they began to put forward proposals about how to reduce the rear-burden attached to the practices developed following the dominant idealistic-idiosyncratic approach.

Within the above mentioned context, this research aims at gaining insights into the trends that can be observed regarding the order of the elements of sentences in Basque among practitioners of the educational arena who are to some extent familiar with the logical-discursive prose but have diverse levels of proficiency at it. Two groups of respondents were analysed: one of them is made up of 8 scholars who have the highest proficiency in the use of the logical-discursive prose in Basque (we call them "experts"); the other group consists of a sample of 212 undergraduate students of the Degree of Primary Education Teacher at the University of the Basque Country, aged around 20.

\subsection{Hypothesis and research questions}

In the context of a possible or supposed evolution of the model pattern concerning the order of the components of the sentence in logi- 
cal-discursive prose, this work aims at exploring the following research questions: 1) which is the tendency about increasing or reducing the rearburden in a given set of Basque sentences among two groups of users of different degrees of language proficiency?; 2) how high is that tendency for each group of respondents? Is there any significant difference between the two groups of users analysed?

These previous questions can be formulated as well in the form of the following two hypotheses: 1) both groups of respondents will show some trend towards organizing elements with a relatively higher rear-burden in the whole set of sentences; hypothetically that outcome would be due to the influence of a trend coming from the beginning of the $20^{\text {th }}$ century that was reborn and predominant at the early stages of the normalization issue in the last third of the century, with its attached assumption that the order of the elements in Basque should be very different (even antagonistic) to the one applying for the surrounding languages (particularly Spanish); 2) that tendency will be higher in the sample of university students than among the members of the group of experts; that would happen because the students have gone through their school career at the time when assumptions in favour of a heavier rear-burden were at a high level.

\subsection{The methodology}

About the sentences analysed. The procedure applied consists of analysing the behaviour of two groups of respondents when dealing with a set of sentences organized with a rear-burden inferior to the one recommended by the "idealistic idiosyncratic approach". A set of 62 items with a (relatively) slight rear-burden was prepared in a questionnaire containing 55 sentences at all and the two groups of respondents were asked to correct the order of the elements of the sentences in case they deemed them as incorrect. This slightly rear-burdened organization of the sentences was primarily proposed to the respondents of the two samples in order to be contrasted with a hypothetical heavier rear-burdened sequence recommended as preferable according to the predominant assumptions of the "idealistic idiosyncratic" approach. Some of the 55 sentences were organized in highly rear-burdened sequences so as to prevent respondents from 
easily realizing which topic was to be studied; they would be used as well to detect any possible trend towards correcting these highly rear-burdened sentences towards sequences with a lower rear-burden.

The respondents. Two groups of respondents with different levels of communicative competence were asked to complete the task of correcting the order of the elements in a set of sentences in case they considered the order proposed was incorrect.

One of the groups consisted of eight users of the language who can be considered as experts having the highest proficiency in the use of the kind of prose analysed. The members of this group of experts were not elected according to any criteria aiming at safeguarding the statistical representativeness of the sample. The function of the members of this group was to contrast their behaviour with younger people's trends, and so to explore the possibility of a tendency towards a better acceptance of a less rear-burdened organization of the elements than the one in force during the time of prevalence of the "idealistic idiosyncratic" approach. In other words, it can be considered as a matter of tolerance towards organizing sentences with a lighter rear-burden. The members of this group were elected because of their great experience in dealing with the kind of logical-discursive prose analysed in this research: four out of eight of them are in charge of a service of the public University of the Basque Country (UPV-EHU) specifically devoted to putting forward, giving advice and/or revising issues related to the use of the Basque language in the university context; the other four members are also active scholars, either full or assistant members of the Basque Academy (Eukaltzaindia, in Basque) very deeply committed to (and updated about) the current development of Basque prose.

The members of the contrast group were 212 undergraduate students in their first academic year at the university being trained on their way to achieve the Degree of Primary Teacher at any one of the three Teacher Training Colleges belonging to the University of the Basque Country (UPV-EHU). They made up $41 \%$ of the total number of students enrolled in the mentioned degree and year; so they can be considered a representative sample of the whole cohort of students of the above mentioned characteristics. These students responded to the questionnaire voluntarily during 2011 without any previous ad-hoc preparation or warning about the topic under study. 
Codification of the information. The elements of the sentences to be analysed were organized with a slight rear-burden and respondents were asked to correct the sentences whose element-order were deemed unacceptable. Each one of the answers was given a value between 0 and 1 . The value 0 was assigned to an item when a given respondent accepted the initially provided sequence, without putting forward any correction by which the rear-burden of the sentence would become higher; an item scored value 1 when a respondent did not accept the provided sentence as it was and thus proposed a correction that made the rear-burden of the sentence higher. Most of the examples scored values 0 or 1 , except for some few cases in which fragmentary scores were assigned depending on the grade of rear-burden proposed by the respondent through his/her alterations.

Then, the general index of the tendency to increase the rear-burden for a given item was drawn by adding up the values assigned to the revision made by all the respondents and then dividing the total score by the number of respondents ( $\mathrm{n} 1=8$, in the case of the group of experts; $\mathrm{n} 2=212$ for the sample of students).

Apart from the index assigned to each item following the above mentioned procedure, another value referring to the profile of the respondents could also be drawn: information has been gathered about the general tendency shown by every respondent related to each one of all the items analysed. Thus, information about different profiles of revisers for the whole set of items studied can be pointed out as well. The procedure for that is the same referred to above: firstly, we obtain the summation of the values assigned to all the corrections, and then we divide that score by the number of items.

An example of an item. This point will be devoted to explaining, through an example we have analysed in our research, the procedure followed to obtain the indexes mentioned above, about the tendency shown by both groups of respondents.

Firstly we present a sentence in its original form in Basque language, with its elements/components organized in two different sequences, both grammatically correct but each one having a different degree of back-burden: (1a) and (1b). We number the elements of the sentences from 1 to 9 , in order to compare the consequences of differing sequences of elements regarding the rear-burden. The item for analysis is always the one in bold letters. 
(1a) Bi aukera ditugu. [Guk], [bigarrena], [hautatu dugu], [uste dugulako] $_{4}$ [irakasleen prestakuntzak] ${ }_{5}$ [eraldaketa hausnartua] ${ }_{6}$ [ekarri behar du- $]_{7}[- \text { ela }]_{8}$ [berarekin $]_{9}$.

(1b) Bi aukera ditugu. [Guk] ${ }_{1}$ [bigarrena] ${ }_{2}$ [hautatu dugu] ${ }_{3}$, [berarekin], [irakasleen prestakuntzak] ${ }_{5}$ [eraldaketa hausnartua] ${ }_{6}$ [ekarri behar du- $]_{7}[- \text { ela }]_{8}$ [uste dugulako $_{4}$.

Secondly, we show their corresponding rough versions in English (2a and $\mathbf{2 b}$ ). The first one, (2a), is basically the order initially proposed as 1a and to be corrected in case the respondent thinks the order of the elements is inacceptable. The second one, (2b), roughly imitates with English words the second alternative sequence possible in Basque (1b).

(2a) We have two options. [We], [have chosen] [the second one], [because we think] ${ }_{4}$ [that] ${ }_{5}$ [teachers' training] ${ }_{6}$ [must bring about], [along with it] ${ }_{8}$ [a meditated change]

(2b) We have two options. [We] [ [have chosen] ${ }_{2}$ the second one] $]_{3}$, [along with it] ${ }_{8}$ [teachers' training] ${ }_{6}$ [a meditated change] ${ }_{9}$ [must bring about $]_{7}[\text { that }]_{5}$ [because we think ${ }_{4}$.

We say that the sentence numbered $\mathbf{2} \mathbf{b}$ has a heavier rear-burden than 2a, because of the position of the crucial element made up by the verb plus the causal marker attached: in the sentence (2a) it takes the $4^{\text {th }}$ place in the sequence whilst in the (2b) version it is pushed back until the $9^{\text {th }}$ position in the sentence.

The variation in the order of the item analysed in this example goes from $4^{\text {th }}$ until $9^{\text {th }}$ place according to these alternative sequences:

(2a) 1-2-3-4-5-6-7-8-9 vs (2b) 1-2-3-8-6-9-7-5-4

As for the number of syllables to be processed before the verb appears in each one of the alternative orders, the difference is clear. In the case of the real Basque example in (1a) the focused element begins at the $11^{\text {th }}$ syllable, while in the (1b) sentence it starts at the $41^{\text {st }}$ place. The difference between those two hypothetic orders takes an amount of 30 syllables. As the element studied (verb plus causal marker) is crucial to gradually and correctly understand the whole message, we say that $\mathbf{2} \mathbf{b}$ has a higher rear-burden and it is communicatively less efficient than the sequence in which this element is put at an earlier position (2a).

However, the real outcome for this item in our research showed a tendency towards increasing the rear-burden estimated at $65 \%$ in the 
sample of students, whilst the experts displayed the same trend in $13 \%$ of the replies. Thus, two elements are noted: 1) both groups of respondents show a tendency towards increasing the rear-burden (when compared to the initial order given for possible correction); 2) the difference between the two groups of respondents is clear $(65 \%-13 \%=52 \%)$, showing the experts much more "tolerant" to sequences with (relatively) little rear-burden than the sample of undergraduate students. As communicatively less efficient utterances are preferred by an important number of respondents in the sample of students, it seems that criteria of communicativeness are not taken as preferential when dealing with the construction of Basque written logical-discursive prose.

\subsection{The outcomes}

The global percentage of the tendency towards increasing the rearburden of the sentences posed for revision is on average $17 \%$ in the group of experts and $61 \%$ in the sample of students (typical deviation being respectively 16.5 and 14.3).

These results show a fairly clear distinction between the two groups of respondents, the most expert group displaying an evidently lower tendency to increase the rear-burden of the sentences provided. The difference is relevant: the global gap on the whole set of sentences between the two groups goes up to $44 \%$. In other words, experts show a higher tolerance to sequences with a slighter rear-burden and thus they would be further away from some assumptions of the "idealistic idiosyncratic" model than the young students in this research.

Some more particular results are shown on the following lines. Of the total amount of 62 items analysed, 24 were not corrected at all by any member of the group of scholars with the highest expertise; that means that $39 \%$ of the items (24 out of 62 ) were accepted without corrections even when they did not follow the pattern promoted by the "idealistic-idiosyncratic" approach. However, in the group of students there was no item to which all the students showed tolerance or acceptance; in every single case, an important amount of revisers of this group of respondents did not accept the sequence initially provided and made corrections to them: the 
"best accepted" item was altered by $23 \%$ of the students. In other words, students showed much lower tolerance to the organization of the elements with a lower rear-burden than the group of experts. So, students followed much more closely the "rules" proposed by the "idealistic-idiosyncratic" approach.

The item mostly corrected by experts was altered by $75 \%$ of them; in contrast, the item mostly modified by students was done so by $93 \%$ of the sample of students.

As to the profile of the respondents we highlight the following points:

1) one of the experts accepted all the sentences with their little initial rear-burden (in other words, his tendency towards increasing the rearburden is 0 ); in contrast, the student who was most "tolerant" to a slight rear-burden altered "only" an $8 \%$ of the items;

2 ) in the group of experts the one who corrected the greatest amount of items did so in $42 \%$ of the cases; in the group of students, the most "active corrector" of the sentences with a slight rear-burden did so in $90 \%$ of the items analysed.

These data show clearly that there is a higher tendency among the students analysed than in the group of experts towards an organization of the elements with a higher rear-burden, despite of the problem generated by that phenomenon about the processing of the message.

\section{Summary and conclusions}

The outcomes of the research show that the older-aged and bestqualified group tends to accept a further reduced rear-burden in more cases than the younger people do. This general result of the research is compatible and even consistent with the assumption of an evolution taking place in the use of Basque logical-discursive prose among practitioners from the educational arena. According to that view, the way to develop Basque discursive prose would have experienced a change over the last 3-4 decades: while at the initial times of the process for normalization and revitalization of the Basque language the predominant pattern for developing the written prose had an important trend towards highly rear-burdened solutions, at this time there would be an increase of the tendency towards a lower rearburden in Basque sentences. 
As for the reasons for that shift, we suggest that, in general terms, the tendency shown by the group of best-qualified users who have been analysed would be due to their awareness of the real communicative difficulties arising when the rear-burden of the sentences becomes heavier. Another relevant reason to explain the differences in behaviour held by the two groups analysed would be related to their ideological position (be it more or less conscious or unconscious) in front of the idealisticidiosyncratic approach that wanted to create the supposed authentic and unique "Basque made prose". Sometime ago the influence of this language ideology was higher than it currently is: nowadays, as the real use of the language increases, highly burdened ideological positions seem to be on their way to being overcome by the factual needs posed by real users of the language in different settings. We suggest that the most expert group is less conditioned by constrictive linguistic ideology in their language use than the younger people, the latter having developed their proficiency after being too simplistically taught that the real good order in Basque sentences is always the one making Basque (even artificially) most different from the languages in its environment.

Finally, we point out that, in our opinion, those changes taking place among users of the language contribute to making Basque prose communicatively more efficient as well as to increasing the possibilities for Basque language to find its place in the concert of a multilingual society with plurilingual speakers.

\section{References:}

Agirre, J. M. (2013). Estilo jarraituaren alde. URL: http://31 eskutik.com/ category/jesus-maria-agirre/ [02/12/2014]

Alberdi X., Sarasola I. (2001). Euskal estilo libururantz. Gramatika, estiloa eta hiztegia. Bilbao: Servicio Editorial UPV-EHU.

Altube S. (1975 [1929]). Erderismos. Bilbao: Cinsa.

Amuriza, X. (2010). Euskara batuaren bigarren jaiotza. Bilbo: Lanku.

Aristegieta X. (2009). Euskarazko testuen komunikagarritasun-problema larriak. Senez, 37, 103-141.

Aristegieta, X. (2012). Zenbait ohar euskarazko hitz-ordenari buruz. Euskera, 57, 3, 505-522.

Berria. (2006). Estilo liburua. Andoain: Berria. 
Euskaltzaindia-Siadeco. (1977). El libro blanco del euskara. Bilbo: Euskaltzaindia-Caja Laboral Popular

Euskaltzaindia (2011). Hitz-ordena. Erabilera estrategikoa. Bilbao: Euskaltzaindia.

EUSTAT (2015).Thematic Statistical Series. URL: http://en.eustat.eus/ bancopx/english/tipo_N/id_2302/indice.html\#axzz3vo67XPAA (accessed 28/12/2015)

Garzia, J. (2014). Esaldiaren antolaera. Funtzio informatiboak gako. Bilbao: Publishing Services of the University of the Basque Country.

Hidalgo, V. (1995). Hitzen ordena euskaraz. URL: http://www.euskara. euskadi.net/appcont/tesisDoctoral/PDFak/bittor_hidalgo.pdf

Hidalgo, B. (2002). Hitzen ordena esaldian, Senez, 25, 75-109.

IVAP. (2005). IVAPeko estilo-liburua. Vitoria-Gasteiz: Inst. Vasco de Admón. Pública

Kaltzakorta, M.( 2007). Prosa komunikagarriago egiten (zenbait proposamen). Bilbao: UEU

Kaltzakorta, M. (2012). Zelan ordenatu egoki informazioa testuetan (I). Lekeitio: Lekeitio/ Markina-Xemein / Ondarroako udalak.

Maia, J. (2014). Euskararen hitz-ordenaren norabidea: idealismo ideologikotik pragmatismo komunikatiborantz. Fontes Linguae Vasconum, 117, 121168.

Maia-Larretxea, J. (2015). On criteria of professionals of the language about the back-burden in Basque, Procedia-Social and Behavioral Sciences, 212 (2), 2015, 67-73.

Mitxelena, L. (1968). Ortografia. Euskera, 13, 203-219.

Villasante, L. (1979). Sintaxis de la oración compuesta. Oiñati: EFA

Villasante, L. (1988). Euskararen auziaz. Estella: EFA.

Zubimendi, J. R., Esnal, P. Idazkera-liburua. Vitoria-Gasteiz: Gobierno Vasco-Consejería de Cultura

\begin{abstract}
This article addresses the issue of the order of the elements in Basque in a setting in which prose is developing to meet new communicative demands made upon this minority language. After outlining some relevant features of the framework of reference of
\end{abstract}


the so-called "rear-burden" in Basque, a research work is presented in which the positions of two groups of respondents from the educational arena with different proficiency levels are analysed, in order to compare their behaviour concerning some slightly rear-burdened sentences. The outcomes show that the group of young university students analysed display a noticeably higher tendency toward sentences with a heavier rear-burden than the trend observed in the group of 8 experts with whom they are contrasted. Two complementary reasons are suggested as an explanation of the results: 1) the experts are more aware of the communicative problems arising by using a heavy rear-burden; 2) young people have been instructed in a learning-environment in which the so-called "idealisticidiosyncratic approach" was in force.

Keywords: Basque language, multilingual society, minority language, written prose developing, word-order in sentences.

\section{Biographical statement}

DR. JULIAN MAIA-LARRETXEA is Professor in the Department of Language and Literature Teaching at the University of the Basque Country. He is member of the research team DREAM (Donostia Research Group on Education and Multilingualism), directed by Durk Gorter. His teaching includes language communicative competence, dialects and standard variety in education, foundations of bilingual education in multilingual settings, and new approaches in language teaching and learning at school. He has conducted research on dialects and education, interferences Spanish-Basque, and the quality of the Basque language in educational settings. Currently he is involved in research about the word-order in Basque in the educational arena.

E-mail: julian.maia@ehu.eus 